\title{
〔論説〕＼cjkstart特集・新しい環境とアセスメントの考察と課題
}

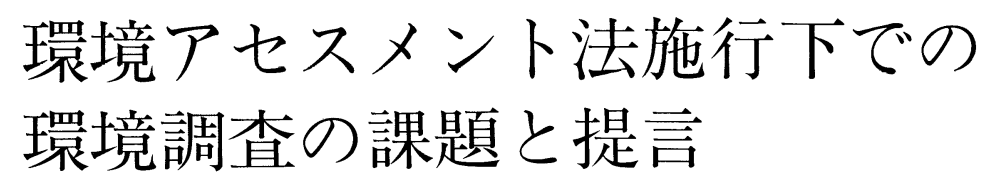

\section{Some Points at Issue of Environmental Surveys and Estimations under the EIA Law}

Masaru ITO : Associate Professor School of Sociology, Edogawa University

$$
\text { *伊藤 勝 }
$$

So many environmental impact assessments (EIAs) had been done by proponents and environmental consultants during three decades or more. They are, ordinary, called "Japanese-original EIA." This expression implies "end-meeting EIA," in Japanese, "awase-ment." New procedures are introduced in the

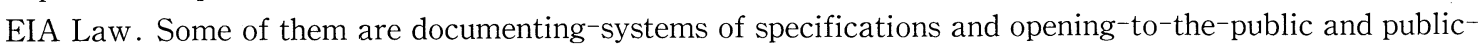
hearing systems.

Because of the Japanese conventions on same-basis and memory-oriented entrance examinations and so forth, decisively-answering, closemouthed-uncertainties and detailed-description are needed in EISs. In the sense, for lack of recognition on communication between proponents and residents, limitations of scientific surveys and estimations and, in addition, decision-making tools, precedents will be maintained in the environmental assessment fields.

For coming and prosperous EIA system in Japan, you will make up clear and accurate reporting system, participating system, guarantees on transparency, specifying preconditions of scientific probabilities and limitations and following-up system.

The EIA Law, specifications, survey, estimation, transparency

環境影響評価法、方法書、環境調査、影響予測、透明性

\section{はじめに}

1999年 6 月には全面施行になる環境影響評価法 を前に，各所で「先取り」や「前倒し」を標榜す る「環境影響評価方法書」の開示や縦覧がなされ ている。これに先立ち, 大阪府や埼玉県では環境 アセスメントに関する条例等に基づき「実施計画 書」等を縦覧したり，ホームページ上に乗せる等 がなされて来な経緯がある（以下，方法書等と記 す)。
これらの方法書等を座右に置きこれまでの閣 議アセスメントや条例・要綱アセスメント, その 他の環境アセスメントの準備書や評価書を踏まえ て，環境調査の課題を明らかにしていく。なお， 個人的な環境アセスメントの経験は限られており， その範囲内での検討になることはご容赦願いたい。

\section{1. 問題提起}

\section{1 ）想起}

三島・沼津で石油コンビナート計画が阻止され

*伊藤 勝 (いとう まさる) ・江戸川大学社会学部環境情報学科助教授 
たのは，1964年のことであった。住民による鯉の ぼりでの風力・風系調査は「身近な環境科学」の 成果と言える。翌年, 通商産業省による「産業公 害総合事前調査」が開始された。1962年にレイチ エル・カーソンの「沈黙の春」が出され, Pasquill -Giffordの式が公表された時期と符合している。 1970年代に入り，手始めとして「鬼怒川左岸台 地工業団地群環境アセスメント」(栃木県)を手掛 けたことが，筆者にとっての初めての総合環境ア セスメント（今思えば，環境アセスメント評価書 (EIS) 作り)である。それ以降, 工業団地, 住宅団 地, 大規模工場, 清掃工場, 発電所等の EIS 作り に従事し, 手続きの支援も行ってきている。前述 の「鬼怒川左岸」では, 住民のモニタリングの可 能性を, 小中学校校庭にある桜の幹に着生するコ ケに求め, 検討した経緯がある。これらの EIS は 行政内資料の水準であり，公害对策の延長線上の 技術書であったことから，住民との関係は多くな かった。

\section{2) 技術論と計画論}

現地調査技術や予測技術の研究開発は, 当時の 公害資源研究所を筆頭とする国の研究機関で推進 され，民間環境コンサルタントへと波及していっ た。精緻化する調査・予測技術（それに内在する 不確実性）は，開発計画の基本となる計画論（的 不確実性）から切り放された。これが「日本式環 境アセスメント」とか「環境アワセメント」と言 われる遠因になるとは, 当時, 気が付かなかった。 予測や調査の前提となる計画や予測 (制約) 条件 を何処かに置き忘れてしまった。戦略的環境ア七 スメントの必要性が世界的に言われていることは, 環境アセスメント先進国と言われる国々でも大同 小異のところが存在するのかも知れない。

\section{3 ）不確実性の視座}

これまでの経験から, 環境アセスメントの対象 事業による個別の不確実性とそれに起因する問題 点 (考えられる検討項目) を幾つか洗い出してみ る。
(1)道路建設：予測の前提となる交通量, 大型車 混入率, 走行速度等は「法定值」以内で計画・ 設定されており，現実と乘離している。污染 原因者は自動車の運行管理者や運転者である。 これへの対応は予測の感度分析と対策効果の 検討であろう。

(2)工業団地：想定業種や規模等（出荷額, 従業 員数, 資材 - 製品輸送 - 消費量, 出荷 - 入荷 先地域）は想定時の計画・設定に基づいてい る。想定業種等の各種原単位に基づく推算想 定值で，立地とは異なる可能性は大である。 包括的コントロール值や立地制限条件の明確 化が必要事項であり, チェック・アンド・レ ヴューが要求されよう。

(3)大規模工場：設置設備のパテントとの関係で 環境アセスメント時の計画では，具体的な設 備計画の確度は低いと言える。包括的枠の設 定と根拠（実証性や担保）が必要であり, 稼 動後のモニタリングへの反映を含むフォロー アップが重要になる。

(4)住宅団地：「住まう」ことと「通う」ことの 想定で左右される。つまり, 想定（客層の） 家族構成, 通勤・通学方向, 公共交通機関・ 端末交通手段等の不確実性があり, 経済社会 の変化に敏感である。計画の変更内容や実態 によって, 環境「見直し」アセスメント（環 境保全図書の变更等) の継続的な実施が考え られる。

(5)発電所：上記の事業に比べて, 計画の実行性 (技術的計画熟度) は高く, 想定条件の担保が 基本となる。この考え方が環境影響評価法の 「電力特例」に反映されたのかもしれない。計 画の不確実性より「推算式の䛊差論」や「現 地調查の地域環境代表性」が課題で，モニ夕 リングを始めとするフォローアップの重要性 が高まる。なお, 電源開発調整審議会（経済 企画庁）と計画アセスメントまたは戦略環境 アセスメントとの関係は課題として残る。 


\section{2. 方法書等の解析}

\section{1）解析の背景}

これまでの環境アセスメントの傾向を概観する と，手続論よりは技術論で語られてきた。その背 景には，環境アセスメントが公害対策の延長線上 にあり，「環境影響評価書 (準備書)」を作ること に主眼を置く傾向が強かったためであろう。つま り，技術オリエンティドな技術書でよく，行政の 技術的判断材料であった。そのため，理解の容易 性には頓着せず（熟れた者にはパターン化され読 みやすくい), 各種事業の計画書に比べて編集や体 裁が貧弱である。

環境影響評価法は, 行政手続法で, 情報公開が 必須として付加された。その結果, 住民関与や住 民参加の意味も重くなり，国民の参加意識も強く なってきている。方法書等の編集に一部改善は感 じられるが，正確（及び正格）を期するあまり， 繰り返しや詳細な記述など, 現在の準備書や評価 書と似たり寄ったりである。一般市民に読みこな されなければならないが，「取っ付き難い」，「分か り難い」ものとなっている。参加を喚起すること も重要であり，方法書等や環境アセスメント書の 編集に際して, 編集力や表現力の向上が望まれる。

他方，国民も「環境を評価」することの前提条 件や拭えぬ不確実性を理解することは必須であり， 科学的な認知行動が期待される。

\section{2 ) 調査・予測項目の整理}

公開された方法書等に記載されている「現地調 査」と「予測項目」について表に纏めた。このよ うな表で調查内容を具体的かつ正確に語ることは 出来ないし，方法書等の持つ「情報量」を言及す ることも出来ない。今後の検討過程で修正・変更 される可能性もあり，文末の「検討した公開方法 書等」に記した一部を掲載する（表一1）に止め る。準備書段階, 評価書段階での項目の変更・追 加とその要因に関する検討も重要なことである。 それらが公開された後に解析していく材料として
位置づける。これらを横断的に比較することで， 事業者の「視点」の差異を浮き彫りに出来ると考 える。

表に見るように，網羅的なものから絞り込んだ ものまで多彩である。立地特性や事業特性（発電 所の場合は，燃料特性等が付加）に基づくもので ある。一面パターン化されているとも採れなくは ないが，微妙な差異もある。保険的に方法書等に 記載しない調査項目も存在する（と思われる）の で，計画内容の変更（環境対策水準の変更やレイ アウト等）と調査・予測項目の追加・変更に注目 していきたい。

\section{3 ) メリハリ}

メリハリのある環境アセスメントが「売り」で ある環境影響評価法の方法書等としては，メリ八 リがあまり感じられない。魅力ある「読み物」と までは要求しないが。総体として総花的傾向と言 える。換言すれば標準的手法に捕らわれ（正格 性)，踏み込んで調查・予測を「行う／行わない」 ことへの決断を避けているように思える。「先陣に はなりたくない」意識か。

方法書等のメリハリには「シナリオ」が必要で ある。「シナリオ」がないから，「何がどうなるか ら，どうする」が読みとり難い。特に，「必要に応 じて」の連発もあるが，「どういう必要か」を明示 しておくべきである（不確実性の明確化の一手 段)。方法書等は縦覧時点での「意志表明」と捉え る。となると,「必要に応じて」追加・付加調査等 を行うことは当然であり, 敢えて書く必要がある のだろうか。

項目間の関連, 解析手順（活用）もウッスラと しか見えてこない。横断的視点が弱いのではない か。極論すると，「環境コンサルタント」割りか。 多くは 1 年間の現地調査と経年的既存資料に基づ き, 予測・評価し，準備書は作られる。内在する 不確実生と限界性をどう示すか。また，国民はど こまで許容，受容する可能性があるのだろうか。 そこにモニタリングを含めたフォローアップを位 


\begin{tabular}{|c|c|c|c|c|c|c|c|c|c|c|c|c|}
\hline \multirow[t]{2}{*}{ 表 -1} & \multicolumn{2}{|c|}{ 方法書の調査項目 } & $\begin{array}{l}\text { 環境アセスメント } \\
\text { 対象事業 } \\
(\quad) \text { 内所在地 }\end{array}$ & \multicolumn{3}{|c|}{\begin{tabular}{|l}
2005 年 \\
日本国際博覽会(要領) \\
(愛知県) H $\quad$ H10-03 \\
\end{tabular}} & \multicolumn{3}{|c|}{ 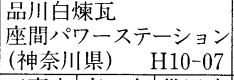 } & \multicolumn{3}{|c|}{\begin{tabular}{|l} 
出光愛知製油所 \\
第 3 発電設備增設 \\
(愛知県) $\quad$ H10-07
\end{tabular}} \\
\hline & \multicolumn{3}{|c|}{ 環 境 要素の区分 } & 工事中 & \begin{tabular}{|l|l} 
存 在 \\
\end{tabular} & 供用時 & 工事中 & 存 在 & 供用時 & 工事中 & 存 在 & 供用時 \\
\hline \multirow{40}{*}{$\begin{array}{l}\text { 環境の } \\
\text { 自然的 } \\
\text { 環境要素 } \\
\text { 良好な } \\
\text { 状態の保持 }\end{array}$} & \multirow[t]{18}{*}{ 大気環境 } & \multirow[t]{5}{*}{ 大気質 } & 二酸化硫黄 & 0 & & 9 & & & & & & - \\
\hline & & & \begin{tabular}{|l} 
二酸化窒素 (窒素酸化物) \\
\end{tabular} & 0 & & 은 & & & - & 0 & & ? \\
\hline & & & 一酸化炭素 & 0 & & 은 & & & & & & \\
\hline & & & 浮遊粒子状物質 & - & & 0 & & & & & & - \\
\hline & & & $\begin{array}{l}\text { 粉じん/降下ばいじん } \\
\text { 有专物質 }\end{array}$ & (c) & & & & & & O & & \\
\hline & & \multirow{3}{*}{ (気象) } & 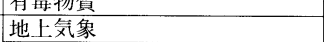 & $\hat{0}$ & & $\vec{O}$ & & & 0 & 0 & & 0 \\
\hline & & & 高層(上層)気象 & & & $\triangle$ & & & & & & 0 \\
\hline & & & 風洞実験 & & & & & & & & & \\
\hline & & 騒音 & 建設工事騒音 & - & & & - & & & 0 & & \\
\hline & & & 交通騒音(陸上) & 운 & & - & & & & - & & - \\
\hline & & & 航空騒音 & & & & & & & & & \\
\hline & & & \begin{tabular}{|l} 
施設騒音 \\
\end{tabular} & & & - & & & - & & & - \\
\hline & & 振動 & 建設工事振動 & - & & & - & & & - & & \\
\hline & & & 交通振動(陸上) & 0 & & - & & & & - & & - \\
\hline & & & 施設振動 & & & & & & - & & & - \\
\hline & & 悪臭 & 锶臭物質 & & & $\Delta$ & & & & & & \\
\hline & & & 奥気濃度 & & & - & & & & & & \\
\hline & & その他 & 低周波音・微気圧波 & 0 & & & & & - & & & - \\
\hline & 水環境 & 水質 & $\mathrm{BOD} / \mathrm{COD}$ & - & & - & & & & & & \\
\hline & & & $\mathrm{pH}$ & 은 & & - & & & & & & \\
\hline & & & SS(濁り) & - & & - & & & & - & & \\
\hline & & & $\mathrm{T}-\mathrm{N}$ & 0 & & 은 & & & & & & 은 \\
\hline & & & \begin{tabular}{|l|} 
T-P \\
その他生活環境項目
\end{tabular} & - & & - & & & & & & 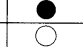 \\
\hline & & & 健康項目 (有害物質) & $\partial / \mathbf{\Delta}$ & & $0 / \boldsymbol{\Delta}$ & & & & & & \\
\hline & & 底質 & 底質 & - & (終了時) & 0 & & & & & & \\
\hline & & 地下水 & 水位・流向 & - & (終了時) & - & & & - & & & \\
\hline & & & 地下水質 & - & (終了時) & - & & & 0 & & & \\
\hline & & （河川） & 流量・流速・水位 & - & & - & & & & & & \\
\hline & & & 水温 & - & & - & & & & & & \\
\hline & & & 河畔環境 & & & - & & & & & & \\
\hline & & (海) & 流量・流速・流向・水位・潮位 & & (沼沢) & 0 & & & & & & \\
\hline & & (湖沼) & 水温 & & (沼沢) & 0 & & & & & (海域) & 0 \\
\hline & & & 海岸環境・湖畔環境等 & & (沼沢) & 0 & & & & & & \\
\hline & & & 水理実験 & & & & & & & & & \\
\hline & 土地環境等 & 地形・地質 & 地形分類・表層地質 & & - & & & & & & & \\
\hline & & & 土地の安全性 & 우 & - & & & & & & & \\
\hline & & 地盤沈下 & 土砂流出・崩壊 & - & 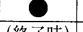 & & & & & & & \\
\hline & & 土袞 & 地盤沈下・隆起・軟弱地盤 & (9) & (終了時) & (2) & & & & & & \\
\hline & & & \begin{tabular}{|l|} 
土堙活染 \\
染
\end{tabular} & (9) & (終了時) & (2) & & & & & & \\
\hline & & その他 & 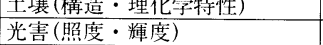 & (C) & (終了時) & (c) & & & & & & \\
\hline 生物多様性 & 植物 & 注月すべき & $\begin{array}{l}\text { 光害 (照度・瓶值䓍) } \\
\text { 剓種 }\end{array}$ & (c) & (終了時) & () & & & & - & 9 & \\
\hline の確保及び & & 植生・注目 & すべき植物群落 (陸域) & 0 & 0 & 0 & & & & - & 0 & \\
\hline 自然環境の & & 植生・注目 & 植物群落 (水域) & 0 & 0 & 0 & & & & & & \\
\hline 体系的保全 & 動物 & 注目すべき & 動物種 (陸域) & - & 0 & - & & & & - & - & \\
\hline & & 注目すべき & 動物種(水域) & - & 0 & - & & & & & & \\
\hline & 生態系 & 生態系 & & 9 & 0 & - & & & & 0 & - & \\
\hline 人と自然との & 景観 & 注目すべき & 景観要素 & 0 & 0 & - & & 0 & & - & - & \\
\hline 豊かな & & 注目すべき & 視点からの眺め & 0 & - & 0 & & - & & - & - & \\
\hline 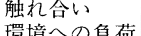 & 触れ合い & 注目すべき & 触れ合い活動の場 & - & - & - & & & & - & & - \\
\hline 溒㑽への)具何 & & 廃衰物等 & 廃棄物 (物質循環) & 은 & & - & & & & - & & 은 \\
\hline & & & 残土 & 0 & & & & & & 0 & & \\
\hline & & & 有機污泥 & - & & $\Delta$ & & & & & & \\
\hline & & & 水循環 & & & - & & & & & & \\
\hline & & 温室効果 & 二酸化炭素等 GHGs & 은 & & - & & & & & & - \\
\hline & & ガス等 & 熱帯材等外材使用 & - & & & & & & & & \\
\hline $\begin{array}{l}\text { その他の項目 (日目 } \\
\text { 凡例 }\end{array}$ & 自治体指定） & 障害・阻害 & 電波障害 & & & & & & & & & \\
\hline 凡例 & & & 日照障害 & & & & & & & & & \\
\hline 8 現地調查 & - 予測 & & 風害 & & & & & & & & & \\
\hline $\begin{array}{ll}9 & \text { 現地調查 } \\
\text { (9) 現地調㭗 }\end{array}$ & & 社会・文化 & 地域分断・地域社会 & & & & & & & & & \\
\hline 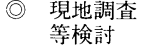 & •状況・対策 & & レクリエーション & & & & & & & & & \\
\hline$\Delta \quad \begin{array}{l}\text { 等検討 } \\
\text { 必要に応 }\end{array}$ & & & 文化財 & & & & & & & & & \\
\hline 查·予測 & 心じ垷地調 & 災害・安全 & 高圧ガス & & & & & & & & & \\
\hline$\triangle$ 必要に応 & じ現地調查 & & 危険物 & & & & & & & & & \\
\hline & & & 交通 & & & & (C) & & & & & \\
\hline
\end{tabular}


置づける必要がある。

\section{3 ・最近の動き}

\section{1）藤前干潟}

廃棄物の埋立最終処分場の必要性は高い。減 量・減容し，安定化して処分することは我が国の 国土特性から必要なことである。この必要性は「何 ものにも優る」ものでないことが明らかにされた。 入口論としての必要性には代替案が必要であり, 政策の効果測定（古くはPPBS 等が検討され た), 影響評価の重要性も明らかになった。廃棄物 の減量政策が基礎になければ, 最終処分場の必要 性も, 干潟の環境保全と比較考量の上, 認められ ないとの判断であろう。護岸根切り残土を用いて 人工干潟を造成するといった「ミチゲーション」 もその影響と効果, 実現可能性等の課題があり, 功を奏しなかった。

「環境への影響」を認めた藤前干潟の埋立環境 アセスメントは，環境調査以前の「代替案検討不 十分」としても結論付けられたが，上述の認知が なければことは起こらなかったかもしれない。政 策の整合性という意味では, 環境保全を嵒ったア ジェンダ 21 との乘離も指摘される。美辞麗句で謳 いあげただけの環境政策への警鐘かも知れない。

\section{2） 光の他の事例}

吉野川可動堰計画は地元市民の住民投票条例の 請願（結果として否決）に至ったが，市民による 代替案の検討, 環境アセスメントの方法の検討等, 一つのエポックを作っているように感じられる。 諌早干拓事業や藤前干潟は, 当初, 住民の意識が 集中せず（関心の低さ又は情報公開の拙さに起因 する), 計画の進行をチェック出来なかった反省材 料となろう。結果として, 前者は事業が推し進め られ，後者はストップした。

ゼネラル石油・川崎製油所の IPP (卸電力供給) の断念も, 環境アセスメントがボディーブローと して利いた感じがする。大気污染防止法の運用と の関係も興味が涌く。少なくとも公開の場を経て
の断念であり，行政指導というベールの中での断 念ではない。川崎市の情報公開条例もあり, 行政 の透明性は良くなってくると期待する。別の角度 から見れば，この透明性は情報公開が定着すれば 当然の帰結になる。この断念への賛否を，個々人 が公開された情報で考えられるようになれば，新 しい展開を生むものと期待している。

2005年愛知万博（複合事業）は環境ア・セスメン トの実施要領が出されて 1 年弱で, 準備書が出さ れた。前倒し現地調查は事業者のリスクの下によ く行われることである。代替案の検討が義務化さ れず，公開されない現法の下では，方法書の縦覧 後, 短期間で準備書の縦覧になるケースは多いと 思われる。ただし，今回の120本のボーリング調査 の実施が環境アセスメントの延長線にあるとは理 解できないことであるが。

\section{4 . 課題と提言}

\section{1）理解の容易性の確保}

「正格」に正確に記すため，技術的でかつ厚く なる。方法書に対して意見を求められても，厚く て読破する時間的余裕はあまりない。『普及版』と 『技術書』に区分してはどうだろうか。『普及版』 の中で詳細を知りたい記載事項は, 『技術書』で検 索できれば良いはずだ。例えば，分析の JIS コー ド等は『技術書』に記載すれば十分である。

記載内容は, 計画の概要と地域環境の概要と特 性, 計画の必要性と代替案の検討, 調査項目と基 本的（行為と直接影響及び二次影響等）考之方, 調査・解析事項の系統的位置付けと期待される成 果, 環境対策の方針と記載可能な具体的対策等で ある。50～60頁が良いところで，これらの技術的 背景は『技術書』に記載すればよい。言うまでも なく, ホームページへの掲載は容易であり, 行政 資料としては『技術書』を用いればよい。高学歴 化に伴い，市民の中には多くの多様な「専門家」 が存在することから，『技術書』はコピーやダウン ロードが容易な別ファイル形式がよいと思う。準 
備書等も記載内容と厚さは増すこととなるが同様 である。

\section{2 ）現地調査の意味と限界の明確化}

学術調査でない原則としての 1 年間の現地調査 には，科学的な限界がある。既存資料と 1 年間の 調查で解ることと解らないことをハッキリさせる べきである。例えば，真の意味での「生態系」は 殆ど解明できないであろう。調査から得られた知 見に基づく「調査者」等の考察や意見，考え方の 提示となろう。頂上生物の食物連鎖，生息基盤と 生息空間の活用等の視点からの考察である。可能 ならば定量的考察が望まれる事業（事業特性と立 地環境特性から）もある。

この限界を克服する手段は, 系統的に組み立て られたモニタリング調查を包含したフォローアッ プである。調查対象項目には，時間遅れで影響が 顕在化するもの, 一過性の影響を受けるもの, 波 及効果として影響を受けるもの，個体で見るか群 （相）として見るか，新たな（想定される）地域環 境の構成要素に組み入れられるものか等, 科学的 系統的な「意味づけ」が準備書作成調査からモ二 タリング調査に渡り要求される。

\section{3）確率論と決定論の峻別}

アセスメントの基本は確率論（蓋然性）である。 計画アセスメントや戦略的アセスメントでは，こ の意味合いは高くなる。反して，技術的計画熟度 が高い事業では決定論的意味が高まり, 勧告, 命 令, 罰則が手続きの過程で可能となる。しかし， 受験勉強の弊害 $(\bigcirc \times$ 的決定論でないと気が済ま ない) があり，「建前」としても事業計画が決定段 階にあるかのような記載になる。例えば，対象事 業の建設段階の「行為量」はこれまでの経験から の推算であり，いくら正確な影響予測式を用いて も，行為量推算の誤差を超える事はできない。ま た，確率論であるべきものを決定論的に扱ってし まう。例えば，交通の安全性（交通事故）の評価 は母集団特性としての評価であり，個々の評価へ の適用は不可能である（血液 $\mathrm{A}$ 型の人々の性格か
ら，A型の特定個人の性格を言うことはできない のと同様である)。従って，対策の記載に止まらざ るを得ない。

\section{4 ) 科学的非科学性の排除}

科学的に構築された推算・予測式には，前提条 件や適用条件がある。これらの条件を満たさない 結果は「参考值」であるべきだ。例えば，道路交 通騒音の予測条件を思い出していただきたい。交 通量と道路条件等の条件があったはずである。新 たに整合条件（補正係数等）を付加しても，当初 の式の科学性は保持できない。行政の参考資料や 環境アセスメントの意思決定の参考資料程度であ れば，そのように明記すべきである。

説明限界も存在する。有効数字もその一つであ るが，ここでは大気拡散の方位性について例示し てみる。点源排ガスの有風時拡散（長期平均）の 横方向拡散は22.5度（1/16方位）均等拡散であ る。長期平均濃度の計算条件として科学的である。 中心角22.5度の扇形で，広がるに従い薄くなるチ

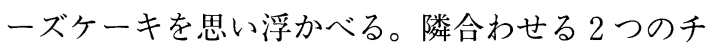
一ズケーキは薄くなる度合いが異なるとする。A はすぐ薄くなる（濃度がすぐ低くなる）が，Bは 薄くなる傾向が少ない（濃度がなかなか下がらな い）とする。 $\mathrm{A} ， \mathrm{~B}$ 両ケーキの縁辺部の隣り合わ せる点の厚さ (濃度) 差は, 何を意味するのであ ろうか。現実の環境濃度の差ではなく，計算条件 に基づく，計算境界近くで生じるある種の「誤差」 である。長期平均濃度の寄与濃度の説明に，この 数値を無原則に用いるなど，限界を超えた説明が なされている場合がある。科学的手順を踏んでい るが非科学的説明であると言える。多煙源である とこの傾向は和らぎ，パラメータフィッティング の条件に近づくが，どの程度の蓋然性が増すかは 言及できない。

\section{5 ）意志決定過程とフォローアップ}

広義の環境アセスメントは, 政策論, 立地論, 計画論を横断的に貫く手続きである。環境アセス メント調査は, これらの三論の意志決定や合意形 
成の資料作りである。三論それぞれ固有に持つ「哲 学」の要件を満たす資料でなければならない。ま た，各段階で完結しているものではなく，継続的 視点が必要である。従って, 公開されるチェック・ アンド・レヴュー（C＆R）がフォローアップに必 要となる。

方法書にあっては，国民意見の反映が如何にな されたかの開示の法的義務はなく，実質的に準備 書を待ななければならない。個人保有情報の活用 とともに，国民の関心（興味）を育成するために も, 修正（補正）方法書の開示は望まれる。「必要 と認めた場合」に追加調查や補足調査は自由なの であるから，それに縛られることはないはず。公 開されれば，準備書段階での住民の参加や関与が 大きく貢献できるものと考える。

以上， 5 点の提言を記載したが, 環境アセスメ ントの不確実性を補完する重要な一方法として, 『フォローアップ計画の中に位置づけられる全工 程での調査と解析，その結果の公開』を結語とし たい。

追記：下記の方法書等の収集は秼東京久栄・アセスメ ント部の協力による。ここに感謝の意を示す。最近の 動向は, 国際影響評価学会日本支部 (IAIA-Japan) のネット情報によるところが大きい。なお， 2 月23日 に「2005年愛知万博」の準備書が公開されたが, 解析 する時間がなかった。
「検討した公開方法書」

1。興亜石油(株)大阪製油所高度化計画に係る環境影 響評価実施計画書, 興亜石油(獭, 平成 5 年 12 月

2.2005年日本国際博覧会に係る環境影響評価実施 計画書，財)2005年日本国際博覧会協会，平成10年 4 月

3.中部国際空港建設事業及び空港島地域開発用地 埋立造成事業に関する環境影響評価方法書, 中部 国際空港(侏)，愛知県，平成 10 年 6 月

4. 品川白煉瓦座間パワーセンター建設事業環境影 響予測評価実施計画書, 品川白煉瓦(株), 平成 10 年 7 月

5 . 出光愛知製油所第 3 号発電設備増設計画環境影 響評価方法書, 出光興産(㑣)愛知製油所, 平成 10 年 7 月

6. 日本石油精製根岸製油所発電設備設置事業に伴 環境影響評価調查計画書, 日本石油精製(梀, 平 成10年 8 月

7. (仮称) 苔蒲町圈央道インタ一周辺土地区画整理 事業に係る環境影響評価方法書, 埼玉県, 平成 10 年 8 月

8. 北陸新幹線（南越（仮称）・敦賀間）環境影響評価 方法書，日本鉄道建設公団，平成 10 年 10 月

8. 徳島飛行場拡張整備事業及び徳島空港周辺整備 計画事業に係る環境影響評価方法書, 運輸省, 運 輸省第三港湾建設局, 徳島県, 平成 10 年 11 月

10. 君津共同発電所 5 号機新設計画環境影響評価方 法書，君津共同火力怢，平成10年11月

11. ユービーイーパワーセンター発電設備環境影響 評価方法書, 株 UBE パワセンター, 平成 10 年 11 月 